\title{
Relationship of antibodies detected by the immunofluorescence method with the various classes of immunoglobulins in cases of untreated syphilis
}

\author{
WANDA MANIKOWSKA-LESIŃSKA AND ADAM JAKUBOWSKI \\ From the Diagnostic Research Centre for Venereal Diseases, Bialystok, Poland (Director : Prof. F. Lesinski)
}

The behaviour and role of the different classes of immunoglobulin in cases of $T$. pallidum infection has not so far been satisfactorily studied. Nearly all those who have dealt with the subject* agree that, in the earliest stages of syphilis, antibodies associated with IgM immunoglobulins predominate, but opinions differ on the role of the various immunoglobulins in the later stages of infection. $\dagger$ The connexion with immunological phenomena and allergy in syphilis has not been explained, nor has it been established whether antibodies belonging to certain immunoglobulin classes are a manifestation of the active syphilitic process (Julian and others, 1969; Király and others, 1969).

Most authors have discussed the relationship between the antibodies detected by various tests for syphilis and the different classes of immunoglobulin.t

The aim of the present investigation was to study the relationship between antibodies detected by the immunofluorescence method and the various classes of immunoglobulin in cases of untreated syphilis.

\section{Material and methods}

Sera were examined from 305 patients, of whom 95 were suffering from primary syphilis, 143 from secondary syphilis, 24 from early latent syphilis, and 43 from late syphilis.

Sera were tested by the indirect immunofluorescence method with the three-layer modification, wherein the $T$. pallidum antigen combines with the antibodies contained in the specimen of serum. In the second phase, a reaction occurs between the syphilitic serum immunoglobulins and the immune monovalent serum obtained by immunizing animals with the appropriate class of human

Received for publication December 3, 1969

*Davis, Moore, Kabat and Harris, 1945; Laurell, 1955; Laurell and Malmquist, 1961; Portnoy, Julian, Smith, and Harris, 1963; Aho, 1967; Julian, Logan, and Norins, 1969.

†Sasahira, 1965; Matuhasi, Mizuoka, and Usui, 1906; Kirlly, Dackhausz, Jobbâgy, Lajos, and Kovâts, 1967; Kirâly, and Jobbâgy, 1969; Manikowska-Lesinska, and Jakubowski, 1969.

$\ddagger$ Tringali, Del Carpio, and Zaffiro, 1968; Tringali, 1969; Tringali, Julian, and Halbert, 1969 ; Jobbâgy. In press. immunoglobulins. In the third phase, the complex previously obtained becomes fixed with the labelled immune serum directed against the globulins of the species of animal used for obtaining the monovalent immune serum in the second phase of the test. This method has already been described in detail (ManikowskaLesińska and others, 1969). The investigations were carried out by means of the quantitative method, the immunofluorescence titre being determined by the technique used in our laboratory (Manikowska-Lesińska, 1964).

\section{Results}

The Figure shows the distribution of immunofluorescent antibodies in the various classes of immunoglobulin in the course of untreated syphilis. The mean titre of the tests made with the various monovalent sera was determined for each stage of syphilis. The total of the mean titres of the three tests was taken to be 100 per cent. and from this were calculated the percentages shown in the diagram.

In the primary stage of syphilis approximately two-thirds of the antitreponemal antibodies detected were in the IgM immunoglobulins: 71 per cent. in primary sero-negative cases, and 61.9 per cent. in primary sero-positive cases. Most of the remaining antibodies were IgG and a very few (4.6 per cent.) were IgA

From the beginning of the secondary stage of syphilis, a marked fall was observed in the percentage of IgM immunlogobulins. In the latent stage of syphilis these antibodies comprised only slightly more than $\mathbf{4 0}$ per cent. of all the fluorescent antibodies. At the same time, there was a marked rise in the antibodies in the IgG class and this reached a maximum during the late latent stage of syphilis, when it comprised 56 per cent. of all antibodies detected.

In late symptomatic syphilis the $\operatorname{Ig} M$ antibodies rose again to form 52 per cent. of all the antibodies detected. The rise in IgM seemed to be particularly 

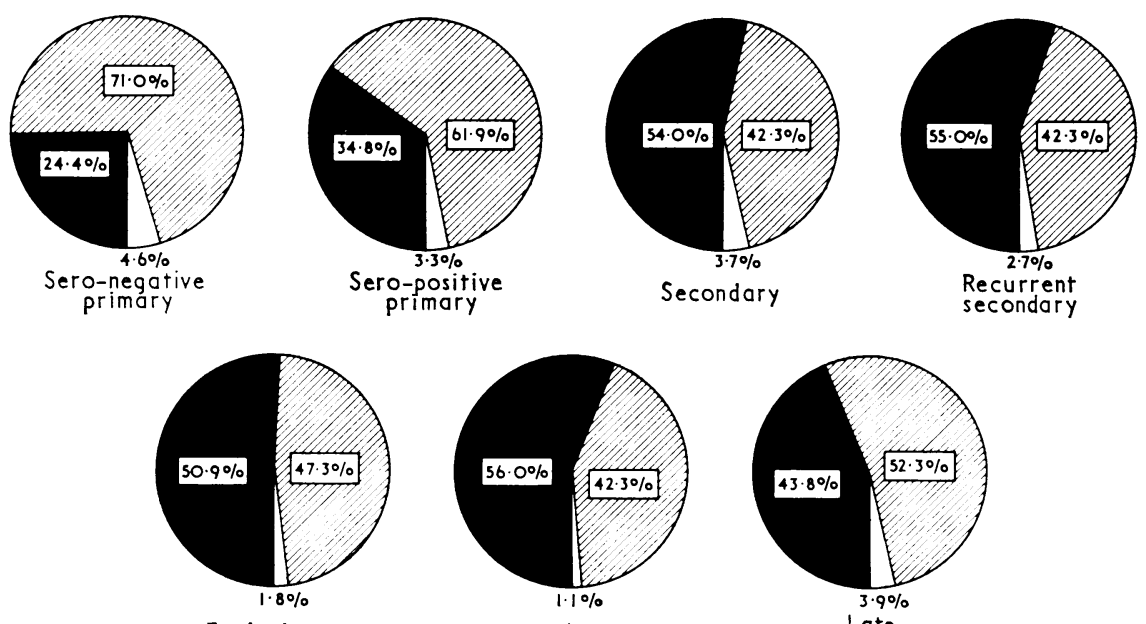

Early latent

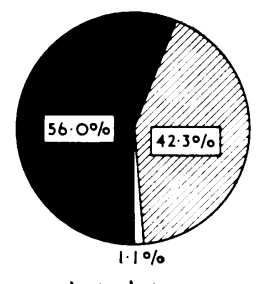

Late latent
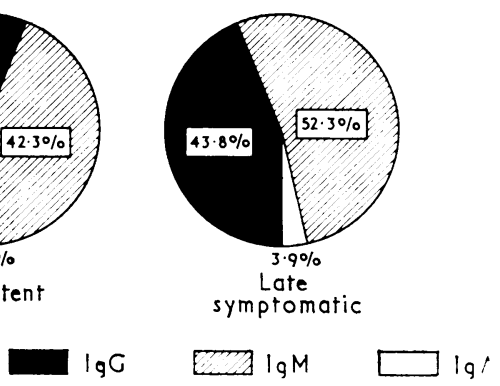

FIGURE Percentage immunofluorescent antibodies belonging to the various immunoglobulin classes during the course of untreated syphilis

marked in active cases of late syphilis, but this observation requires further investigation on a wider scale and for a longer period of time.

\section{Discussion and conclusions}

These results confirm our previous observations and also the reports of Király and others $(1967,1969)$ and of Merklen Buzacoux, and Potier (1968). During the primary stage of syphilis, particularly in sero-negative cases, most of the antibodies detected by the FTA test belong to the IgM class of immunoglobulins, a quarter to the $\operatorname{IgG}$, and less than 5 per cent. to the IgA. In the later stages of infection, a marked increase in the percentage of IgG antibodies occurs at the expense of the IgM and IgA. In late syphilis, however, and particularly symptomatic late syphilis, most of the antitreponemal antibodies are IgM, which is contrary to the observations of Matuhasi and others (1966) and Sasahira (1965), but it was not possible to tell whether this was a manifestation of active infection.

\section{Summary}

1) The antibodies detected in cases of untreated syphilis belong to all three immunoglobulin classes regardless of the stage of syphilis.

2) In the primary stage, particularly in sero-negative cases, the majority of antibodies are in the $\operatorname{IgM}$ fraction. In the later stages, the percentage belonging to the IgG fraction rises.

3) The increase in the percentage of $\operatorname{IgM}$ antibodies in cases of symptomatic late syphilis requires further investigation to discover the relationship between $\operatorname{IgM}$ and the activity of the syphilitic process.

\section{References}

Aно, K. (1967) Brit. F. vener. Dis., 43, 259

Davis, B. D., Moore, D. H., Kabat, E. A., and Harris, A. (1945) F. Immunol., 50, 1

JobBáGY, A. 'Pamiętnik XIX Ziazdu PTD, Warszawa'. In press

Julian, A. J., Logan, L. C., and Norins, L. C. (1969) WHO VDT RES 69.166

Király, K., Backhausz, R., Jobbágy, A., Lajos, J., and KovÁts, L. (1967) WHO VD'T RES 67.130

— and Jobbágy, A. (1969) 'Pamiętnik VI Posiedzenia Naukowego Sekcji Wenerologicznej PTD', p. 55. Ed. Tarchomińskie Zakłady Farmaceutyczne POLFA, Białystok-Warszawa

Laurell, A.-B. (1955) Acta path. microbiol. scand., Suppl. 103 'On antibodies separated by paper electrophoresis with special reference to the Wassermann reagins'

- and MalmQuist, J. (1961) Ibid., 51, 187

Manikowska-Lesińska, W. (1964) Pol. Tyg. lek., 19, 1833

— and Jakubowski, A. (1969) 'Pamiętnik VI Posiedzenia Naukowego Sekcji Wenerologicznej PTD', p. 71. Ed. Tarchominskie Zakłady Farmaceutyczne POLFA, Białystok-Warszawa

Matuhasi, T., Mizuoka, K., and Usui, M. (1966) Bull. Wld Hlth Org., 34, 466

Merklen, F. P., Buzacoux, J., and Potier, J. C. (1968) Bull. Soc. franf. Derm. Syph., 75, 57

Portnoy, J., Julian, A. J., Smith, J. F., and Harris, A. (1963) Brit. F. vener. Dis., 39, 33

SASAhira, T. (1965) Fap. F. Bact., 20, 183

TRINGali, G. (1969) WHO VDT RES 69.171 
Del Carpio, C., and Zafriro, P. (1968) WHO/ VDT/RES/68.154

, JULIAN, A., and HALBERT, W. (1969) WHO/VDT/ RES/69.168

Relation entre les anticorps mis en évidence par

la méthode de l'immuno-fluorescence et les différents groupes d'immuno-globulines dans la syphilis non traitée

SOMMAIRE

(1) Les anticorps révélés par l'épreuve FTA appartiennent aux trois groupes d'immuno-globulines, quel que soit le stade de la syphilis.

(2) Au stade primaire, particulièrement dans les cas séronégatifs, la majorité des anticorps appartient à la fraction IgM. Dans les stades ultérieurs, la proportion d'anticorps IgG augmente.

(3) L'augmentation de la proportion d'anticorps IgM dans les cas de syphilis latente symptomatique nécessite des recherches supplémentaires pour découvrir la relation entre ces anticorps IgM et l'activité de la syphilis. 